\title{
Thermocyclops decipiens (Kiefer, 1929) (Copepoda, Cyclopoida) as Indicator of Water Quality in the State of Minas Gerais, Brazil
}

\author{
Giovanni Guimarães Landa ${ }^{1 *}$, Francisco Antonio Rodrigues Barbosa ${ }^{1}$, Arnola Cecilia Rietzler ${ }^{2}$ \\ and Paulina Maria Maia-Barbosa ${ }^{3}$ \\ ${ }^{I}$ Programa de Pós-Graduação em Ecologia; Conservação e Manejo da Vida Silvestre; Laboratório de Limnologia; \\ ${ }^{2}$ Laboratório de Ecotoxicologia; ${ }^{3}$ Laboratório de Ecologia de Zooplâncton; Departamento de Biologia Geral; Instituto \\ de Ciências Biológicas; Universidade Federal de Minas Gerais; C.P. 486; gflanda@ig.com.br; 31270-901; Belo \\ Horizonte - MG - Brasil
}

\begin{abstract}
The aim of this work was to study the possible utilization of Thermocyclops decipiens as indicator of the trophic degree and water quality of some watersheds of the state of Minas Gerais. From the beginning of the decade of 90 , $\underline{T}$. decipiens was recorded in several water collections of the state, including the basins of the rivers Paranaíba, São Francisco, Doce and Grande, within environments mainly of meso and eutrophics characteristics. Of the 28 places of occurrence of the species and according to the water quality index (WQI) used by Environmental Foundation of Minas Gerais (FEAM), 7 of these environments presented WQI good, 16 medium, 4 bad and one very bad. This classification corroborated the hypothesis that $\underline{T}$. decipiens could be used as indicator species of eutrophic environments and of low water quality thus constituting an important tool for the biomonitoring of aquatic ecosystems.
\end{abstract}

Key words: Thermocyclops decipiens, water quality, bioindicator

\section{INTRODUCTION}

The genus Thermocyclops is considered a genus of tropical origin that according to Kiefer (1938) presents a notable variety at local level, giving place to the description of a lot of restricted distribution species. In the neotropical region, this genus is relatively poor in species. T. minutus is a common species, restricted to South America, mainly in Brazil (Rocha et al., 1995; Sampaio and López, 2000). T. decipiens also has a wide distribution, and in many places, these two species can occur together.
The trophic state of lakes, or reservoirs seems to determine the occurrence of these species.In oligotrophic waters $T$. minutus is more frequent while, in eutrophic waters it is substituted by $T$. decipiens and in mesotrophic waters, the two species are found together, or alternately, according to the seasonal variation (Rocha et al., 1995). According to Hutchinson (1951), T. decipiens is a pioneering species of great dispersion and highly adaptable to colonize new environments, such as reservoirs and artificial water bodies. This species was cited for the first time in Brazil by Carvalho

\footnotetext{
${ }^{*}$ Author for correspondence
} 
(1975), in Americana Reservoir (SP) as $T$. crassus, and according to Sendacz and Kubo (1982) this was the species among Cyclopoida, most broadly distributed in reservoirs of the state of São Paulo.

$T$. decipiens is commonly found in environments of the southeast of Brazil, with meso and eutrophic characteristics, being able to serve as indicative species of the trophic degree (Reid et al., 1988) and therefore, studies of its biology become extremely important. $T$. decipiens new distribution areas include Antilles, Central America, Colombia, Venezuela and east of the Andes and extensive areas in the Brazilian territory. In Argentina, there are some registrations in the north (Reid, 1989). According to Reid (1985), it is a pantropical species, eurytopic in lakes, swamps and ephemeral waters, broadly distributed in South and Central America. As the other members of the genus, don't inhabit high altitudes, or areas to the west of Andes, the limits of its distribution to the east of these mountains are still unknown. The Argentinean registrations of Bonetto and Martinez de Ferrato (1966) and of Matinez de Ferrato (1967) identified them as T. hyalinus. Paggi and José de Paggi (1990) in Middle Paraná and MenuMarque (1982) in the River Hondo Reservoir, north of Argentina, apparently showed the limits more in the south. Other more recent registrations, also to the south, but in Brazilian territory in the floodplain of the river Paraná basin are of LansacTôha et al. (1992; 2002) among others.

In the southeast region of Brazil, T. decipiens was registered only in the states of São Paulo and Minas Gerais.

Considering the dominance of $T$. decipiens in the Pampulha Reservoir and its probable relation with the trophic degree, the present work had as an objective to verify the possibility of using this organism as a trophic degree indicator and/or water quality of some watersheds of the state of Minas Gerais.

\section{MATERIALS AND METHODS}

A bibliographical survey of the occurrence of $T$. decipiens in the state of Minas Gerais was made besides using the database (SISAGUA) of CEMIG (Energy Company of Minas Gerais), internal reports of COPASA (Company of Sanitation of Minas Gerais) and reports of IGAM (Mining
Institute of Administration of the Waters), from the period of 2002 and 2003. The methodological synthesis of collection is described in the Table 1 .

To relate the occurrence of $T$. decipiens with the water quality in the watersheds, data of the project Águas de Minas was used, regarding the monitoring of the water quality of the state of Minas Gerais, using WQI (Water Quality Index) (CETESB, 1989).

\begin{tabular}{cc}
\hline Quality Level & Scale \\
\hline Excellent (blue) & $90<$ WQI $<=100$ \\
Good (green) & $70<$ WQI $<=90$ \\
Medium (yellow) & $50<$ WQI $<=70$ \\
Bad (orange) & $25<$ WQI $<=50$ \\
Very bad (red) & $00<$ WQI $<=25$ \\
\hline
\end{tabular}

\section{RESULTS}

In the state of Minas Gerais, the first record of $T$. decipiens was in the Varzea das Flores Reservoir during the period from 1984 to 1985 (Freire and Pinto-Coelho, 1986), in Lagoa Santa in 1985 and in the Pampulha Reservoir from 1984 to 1985 (Reid et al., 1988). From the beginning of the 90's decade, this species was registered all over the state, including the basins of the rivers Paranaíba, São Francisco, Doce and Grande, although, they were absent in the basins of the rivers Jequitinhonha, Mucuri, Paraíba do Sul, Piracicaba and Pardo (Table 2). These four basins are considered the most representative of the state of Minas Gerais, being specially subjected to the anthropic activities. The progressive development of economical activities and the disordered population growth have been altering drastically the water quality and quantity.

Of the 28 places where this species occurred, 12 were lotic environments, 1 was a pond and 15 reservoirs. In terms of water quality and WQI, 7 were classified as good, 16 as medium, 4 as bad and 1, Pampulha Reservoir, as very bad. Of these 28 places, 7 belong to the Paranaíba River basin, 11 to the São Francisco River basin, 3 to the Doce River basin and 7 in the Grande River basin. 
Table 1 - Methodological Synthesis used to collect Thermocyclops decipiens in the state of Minas Gerais

\begin{tabular}{|c|c|c|c|}
\hline Basin & Local & Methodology & Reference \\
\hline Paranaíba & $\begin{array}{l}\text { Streamlet Santo Antônio, } \\
\text { River Araguari, } \\
\text { River Paranaíba, } \\
\text { River Quebra Anzol }\end{array}$ & $\begin{array}{l}\text { Filtering with bucket and a plankton } \\
\text { net }\end{array}$ & CEMIG, 1994 \\
\hline Paranaíba & Nova Ponte Reservoir & Vertical tow with a plankton net & Silva, 1998 \\
\hline São Francisco & River Pará & $\begin{array}{l}\text { Filtering with bucket and a plankton } \\
\text { net }\end{array}$ & CEMIG, 1994 \\
\hline Paraopeba/ São Francisco & $\begin{array}{l}\text { Várzea das Flores } \\
\text { Reservoir }\end{array}$ & Kemmerer's bottle & $\begin{array}{l}\text { Freire e Pinto-Coelho, } \\
1986\end{array}$ \\
\hline Paraopeba/ São Francisco & Serra Azul Reservoir & Vertical tow with a plankton net & COPASA, 1999 \\
\hline Paraopeba/ São Francisco & $\begin{array}{l}\text { Ibirité Reservoir } \\
\text { REGAP) }(* *)\end{array}$ & $\begin{array}{l}\text { Vertical tow with a } 65 \mu \mathrm{m} \text { plankton } \\
\text { net }\end{array}$ & Pinto-Coelho et al., 1998 \\
\hline São Francisco & $\begin{array}{l}\text { Reservoirs of Rio Manso } \\
\text { and Juramento }\end{array}$ & Vertical tow with a plankton net & COPASA, 1999 \\
\hline São Francisco & Três Marias Reservoir & $\begin{array}{l}\text { Vertical tow with a } 68 \mu \mathrm{m} \text { plankton } \\
\text { net }\end{array}$ & $\begin{array}{l}\text { Sampaio e López (in } \\
\text { preparation) }\end{array}$ \\
\hline Velhas/ São Francisco & Pampulha Reservoir & $\begin{array}{l}\text { Vertical tow with a } 90 \mu \mathrm{m} \text { plankton } \\
\text { net }\end{array}$ & Pinto-Coelho et al., 1999 \\
\hline Velhas/ São Francisco & PUC-Minas Reservoir & $\begin{array}{l}\text { Vertical tow with a } 35 \mu \mathrm{m} \text { plankton } \\
\text { net }\end{array}$ & $\begin{array}{l}\text { Landa (data not } \\
\text { published) }\end{array}$ \\
\hline Velhas/ São Francisco & Lagoa Santa & Tows with a plankton net & $\begin{array}{l}\text { Reid; Pinto-Coelho; } \\
\text { Giani, } 1988\end{array}$ \\
\hline Rio Doce & Pontal Reservoir & Vertical tow with a plankton net & Dabés et al., 1990 \\
\hline Rio Doce & $\begin{array}{l}\text { River Santo Antônio and } \\
\text { River Guanhães }\end{array}$ & $\begin{array}{l}\text { Filtering with bucket and a plankton } \\
\text { net }\end{array}$ & CEMIG, 1994 \\
\hline Rio Grande & Pomar Reservoir & $\begin{array}{l}\text { Vertical tow with a } 35 \mu \mathrm{m} \text { plankton } \\
\text { net }\end{array}$ & $\begin{array}{l}\text { Landa e Mourgues- } \\
\text { Schurter, } 1999\end{array}$ \\
\hline Rio Grande & $\begin{array}{l}\text { Nova and Estação } \\
\text { Reservoirs }\end{array}$ & $\begin{array}{l}\text { Vertical tow with a } 35 \mu \mathrm{m} \text { plankton } \\
\text { net }\end{array}$ & $\begin{array}{l}\text { Landa e Mourgues- } \\
\text { Schurter, 2000a }\end{array}$ \\
\hline Rio Grande & $\begin{array}{l}\text { Station of Fish Farming of } \\
\text { UFLA }(*)\end{array}$ & $\begin{array}{l}\text { Filtering with bucket and a } 35 \mu \mathrm{m} \\
\text { plankton net }\end{array}$ & $\begin{array}{l}\text { Landa e Mourgues- } \\
\text { Schurter, 2000b }\end{array}$ \\
\hline Rio Grande & Volta Grande Reservoir & $\begin{array}{l}\text { Vertical tow with a } 35 \mu \mathrm{m} \text { plankton } \\
\text { net }\end{array}$ & Rolla et al., 1990 \\
\hline Rio Grande & River Grande & $\begin{array}{l}\text { Filtering from } 100 \text { to } 200 \mathrm{~L} \text { with } \\
\text { bucket and a } 35 \mu \mathrm{m} \text { plankton net }\end{array}$ & Rolla et al., 1992 \\
\hline Rio Grande & Furnas Reservoir & $\begin{array}{l}\text { Tows with a plankton net }(1) \\
\text { Vertical tow with a } 90 \mu \mathrm{m} \text { plankton } \\
\text { net (2) }\end{array}$ & $\begin{array}{l}\text { Reid e Pinto-Coelho, } \\
1994 \text { (1); Rull Del } \\
\text { Aguila, } 2001 \text { (2) }\end{array}$ \\
\hline
\end{tabular}

* UFLA - Universidade Federal de Lavras; ** REGAP - Refinaria Gabriel Passos

Table 2 - Occurrence of Thermocyclops decipiens in the state of Minas Gerais

\begin{tabular}{|c|c|c|c|c|c|c|}
\hline Basin & Water body & WQI & Reservoir & Municipal district & Coordinates & Reference \\
\hline Paranaíba & $\begin{array}{c}\text { Streamlet Santo } \\
\text { Antônio }\end{array}$ & Medium & Nova Ponte & Nova Ponte & $\begin{array}{l}19^{\circ} 06^{\prime} 54^{\prime \prime} / \\
47^{\circ} 16^{\prime} 43^{\prime \prime}\end{array}$ & CEMIG, 1994 \\
\hline Paranaíba & River Araguari & Good & Nova Ponte & Nova Ponte & $\begin{array}{l}19^{\circ} 33^{\prime} 08^{\prime \prime} / \\
47^{\circ} 03^{\prime} 33^{\prime \prime}\end{array}$ & CEMIG, 1994 \\
\hline Paranaíba & River Araguari & Medium & Nova Ponte & Sacramento & $\begin{array}{l}19^{\circ} \quad 07^{\prime} 59^{\prime \prime} / 4^{\circ} \\
41^{\prime} 37^{\prime \prime}\end{array}$ & CEMIG, 1994 \\
\hline Paranaíba & River Paranaíba & Medium & Emborcação & Abadia dos Dourados & $\begin{array}{l}18^{\circ} 04^{\prime} 51^{\prime \prime} / 4^{\circ} \\
28^{\prime} 33^{\prime \prime}\end{array}$ & CEMIG, 1994 \\
\hline Paranaíba & River Paranaíba & Good & São Simão & Cachoeira Dourada & $\begin{array}{l}18^{\circ} \quad 57^{\prime} 57^{\prime \prime} / 4^{\circ} \\
36^{\prime} 42^{\prime \prime}\end{array}$ & CEMIG, 1994 \\
\hline Paranaíba & & Good & Nova Ponte & Nova Ponte & $19^{\circ} 10^{\prime} / 47^{\circ} 30^{\prime}$ & Silva, 1998 \\
\hline Paranaíba & $\begin{array}{l}\text { River Quebra } \\
\text { Anzol }\end{array}$ & Medium & Nova Ponte & Nova Ponte & $\begin{array}{l}19^{\circ} 26^{\prime} 54^{\prime \prime \prime} \\
46^{\circ} 54^{\prime} 03^{\prime \prime}\end{array}$ & CEMIG, 1994 \\
\hline São Francisco & River Pará & Medium & $\begin{array}{l}\text { Carmo do } \\
\text { Cajuru }\end{array}$ & Carmo do Cajuru & $\begin{array}{l}20^{\circ} 57^{\prime} 20^{\prime \prime \prime} \\
44^{\circ} 49^{\prime} 27^{\prime \prime}\end{array}$ & CEMIG, 1994 \\
\hline
\end{tabular}




\begin{tabular}{|c|c|c|c|c|c|c|}
\hline Basin & Water body & WQI & Reservoir & Municipal district & Coordinates & Reference \\
\hline São Francisco & River Pará & Good & $\begin{array}{l}\text { Carmo do } \\
\text { Cajuru }\end{array}$ & Carmo do Cajuru & $\begin{array}{l}20^{\circ} 16^{\prime} 25^{\prime \prime} / \\
44^{\circ} 52^{\prime} 40^{\prime \prime}\end{array}$ & CEMIG, 1994 \\
\hline $\begin{array}{l}\text { Paraopeba/ São } \\
\text { Francisco }\end{array}$ & & $\mathrm{Bad}$ & $\begin{array}{l}\text { Várzea das } \\
\text { Flores }\end{array}$ & Betim/ Contagem & $19^{\circ} 55^{\prime} / 44^{\circ} 02^{\prime}$ & Freire e Pinto-Coelho, 1986 \\
\hline Paraopeba/ São & & Medium & Serra Azul & Mateus Leme & $19^{\circ} 58^{\prime} 18^{\prime \prime} /$ & COPASA, 1999 \\
\hline Francisco & & & & & $44^{\circ} 20^{\prime} 45^{\prime \prime}$ & \\
\hline Paraopeba/ São & & $\mathrm{Bad}$ & Ibirité (REGAP) & Ibirité/ Betim & $20^{\circ} 03^{\prime} 05^{\prime \prime}$ & Pinto-Coelho et al., 1998 \\
\hline Francisco & & & & & $44^{\circ} 19^{\prime} 03^{\prime \prime}$ & \\
\hline São Francisco & & Medium & River Manso & Brumadinho & $\begin{array}{l}20^{\circ} 08^{\prime} 38^{\prime \prime} / \\
44^{\circ} 15^{\prime} 27^{\prime \prime}\end{array}$ & COPASA, 1999 \\
\hline São Francisco & & Medium & Juramento & Juramento & $\begin{array}{l}16^{\circ} 51^{\prime} 08^{\prime \prime \prime} \\
43^{\circ} 35^{\prime} 14^{\prime \prime}\end{array}$ & COPASA, 1999 \\
\hline São Francisco & & Medium & Três Marias & Três Marias & $18^{\circ} 12^{\prime} / 45^{\circ} 15^{\prime}$ & $\begin{array}{l}\text { Sampaio e López } \\
\text { preparation) }\end{array}$ \\
\hline $\begin{array}{l}\text { Velhas/ São } \\
\text { Francisco }\end{array}$ & Lagoa Santa & $\mathrm{Bad}$ & & Lagoa Santa & $19^{\circ} 38^{\prime} / 43^{\circ} 53^{\prime}$ & $\begin{array}{l}\text { Reid; Pinto-Coelho; Giani, } \\
1988\end{array}$ \\
\hline Velhas/ São & & Medium & PUC-Minas/BH & Belo Horizonte & $19^{\circ} 55^{\prime} 09^{\prime \prime}$ & Landa (data not published) \\
\hline Francisco & & & & & $43^{\circ} 56^{\prime} 47^{\prime \prime}$ & \\
\hline Velhas/ São & & Very Bad & Pampulha & Belo Horizonte & $19^{\circ} 55^{\prime} 09^{\prime \prime} /$ & Pinto-Coelho et al., 1999 \\
\hline Francisco & & & & & $43^{\circ} 56^{\prime} 47^{\prime \prime}$ & \\
\hline Rio Doce & & $\mathrm{Bad}$ & Pontal & Itabira & $\begin{array}{l}19^{\circ} 36^{\prime} 31^{\prime \prime} / \\
43^{\circ} 11^{\prime} 31^{\prime \prime}\end{array}$ & Dabés et al., 1990 \\
\hline Rio Doce & $\begin{array}{l}\text { River Santo } \\
\text { Antônio }\end{array}$ & Medium & Salto Grande & Braúnas & $\begin{array}{l}19^{\circ} 16^{\prime} 40^{\prime \prime} / \\
42^{\circ} 47^{\prime} 14^{\prime \prime}\end{array}$ & CEMIG, 1994 \\
\hline Rio Doce & River Guanhães & Medium & Salto Grande & Braúnas & $\begin{array}{l}19^{\circ} 04^{\prime} 36^{\prime \prime} / \\
42^{\circ} 50^{\prime} 54^{\prime \prime}\end{array}$ & CEMIG, 1994 \\
\hline Rio Grande & & Medium & Pomar & Lavras & $21^{\circ} 30^{\prime} / 45^{\circ} 10^{\prime}$ & $\begin{array}{l}\text { Landa e Mourgues-Schurter, } \\
1999\end{array}$ \\
\hline Rio Grande & & Medium & Nova & Lavras & $21^{\circ} 30^{\prime} / 45^{\circ} 10^{\prime}$ & $\begin{array}{l}\text { Landa e Mourgues-Schurter, } \\
\text { 2000a }\end{array}$ \\
\hline Rio Grande & & Medium & $\begin{array}{l}\text { Station of Fish } \\
\text { Farming }\end{array}$ & Lavras & $21^{\circ} 30^{\prime} / 45^{\circ} 10^{\prime}$ & $\begin{array}{l}\text { Landa e Mourgues-Schurter, } \\
2000 \text { b }\end{array}$ \\
\hline Rio Grande & & Medium & Estação & Lavras & $21^{\circ} 30^{\prime} / 45^{\circ} 10^{\prime}$ & $\begin{array}{l}\text { Landa e Mourgues-Schurter, } \\
\text { 2000a }\end{array}$ \\
\hline Rio Grande & & Good & Volta Grande & $\begin{array}{c}\text { Conceição das Alagoas, } \\
\text { Agua Comprida e } \\
\text { Uberaba }\end{array}$ & $\begin{array}{l}20^{\circ} 08^{\prime} 32^{\prime \prime} / \\
48^{\circ} 11^{\prime} 39^{\prime \prime}\end{array}$ & $\begin{array}{l}\text { Rolla et al., 1990; Greco, } \\
2002\end{array}$ \\
\hline Rio Grande & River Grande & Good & Igarapava & Sacramento/ Conquista & $\begin{array}{l}20^{\circ} 05^{\prime} \quad 55^{\prime \prime} / 47^{\circ} \\
32^{\prime} 50^{\prime \prime}\end{array}$ & Rolla et al., 1992 \\
\hline Rio Grande & & Good & Furnas & São José da Barra & $\begin{array}{l}20^{\circ} 31^{\prime} 42^{\prime \prime} / 46^{\circ} \\
08^{\prime} 45^{\prime \prime}\end{array}$ & $\begin{array}{l}\text { Reid e Pinto-Coelho, 1994; } \\
\text { Rull Del Aguila, } 2001\end{array}$ \\
\hline
\end{tabular}

\section{DISCUSSION}

Considering the diversity of environments where $T$. decipiens has been registered, either lotic or lentic, small or big in size, it can be considered as an euryoic species (Menu-Marque, 1982). T. decipiens is commonly found and frequently numerous in big and small lakes and in meso and eutrophic reservoirs, as well as in small water springs (Reid, 1989).

The enrichment of water body with essential nutrients (nitrogen and phosphorus) is one of the first causes of the eutrophication (Ryding and Rast, 1989), and one of the most evident consequences of that enrichment is the change of the physical and chemical conditions of the environment in which the zooplanktonic community develops. Among other effects, the most direct is the variation in the composition of phytoplanktonic species, as well as the presence of bacteria and debris in the environment, determining, in that way the quantity and the quality of the available food for the zooplankton, favoring species of smaller size, such as $T$. decipiens.

In the Paranaíba River basin, of the seven places where the species was found, four presented a medium WQI, with waters characteristics from meso to eutrophic. The waters of Paranaíba River basin are predominantly bland, lightly acid, with low contents of dissolved salts. A great spatial and temporal variability was related to the concentration of suspended solids (organic and fecal); very expressive values occurred in the sampling stations located in the head of the Paranaíba River and in smaller tributaries. On the other hand, downstream of the big reservoirs located in the main course and in the Araguarí 
River in the same basin, there was an inversion of that situation as a consequence of the stabilization observed in dammed environments (IGAM, 2003). In general, the waters were very oxygenated and rich in iron and manganese. At this basin, the highest concentrations of total phosphate was observed in the state of Minas Gerais. Those characteristics suggested waters with medium quality; good conditions occured in the lower passages of the main course and medium conditions in the upper passages and in the Araguarí River sub-basin.

In this sub-basin, the food, metallurgic, chemistry and fertilizer industries, besides farming and stockbreeding are the dominant economical activities. Clay and peat exploration are also important in this sub-basin. In the high course of Paranaiba River, mining activities, such as phosphate exploration are present, besides food industries. The analysis of these aspects allows to concluded that the main problems of water quality of the Paranaíba River basin are associated to effluents of gross sanitary sewers and the inadequate agricultural use and handling of the soil. The effect of the use and disordered occupation of the soil in the areas drained by the river Paranaíba, upstream of the reservoir of Emborcação, by the river Quebra Anzol and by the river Araguarí, upstream of Nova Ponte's reservoir is relevant, as it is demonstrated in the registrations of solids and turbidity (IGAM, 2003). These areas corresponded to the places where $T$. decipiens occurred, corroborating the suggestion of a relation between the distribution of this species and the predominant environmental conditions. Thus, the phosphorus contents were very high (reaching up to $0.6 \mathrm{mg} . \mathrm{L}^{-1}$ ) compromising the water quality of Paranaíba River, favoring the predominance of $T$. decipiens. As for Nova Ponte Reservoir, even presenting a good water quality index, Silva (1998) registered the species $T$. decipiens, in high densities in periods of more eutrophic characteristics.

In San Francisco River basin, of the eleven places where the species was found, two corresponded to the Pará River sub-basin, one being upstream of the Carmo do Cajuru Reservoir, with medium WQI and the other downstream of the same reservoir, with WQI considered good. The content of suspended solids was clearly larger in the region of the heads of the Pará River upstream the dam of Carmo do Cajuru, where downstream, the values detected were lower, as well as in the main course and in the main tributaries. The phosphate concentrations were above the acceptable limits for waters of class $2\left(0.025 \mathrm{mg} . \mathrm{L}^{-1}\right)$ according to the resolution $\mathrm{n}^{\circ} 20$ of CONAMA (1986), in the great majority of the determinations (IGAM, 2003).

Alterations of the water quality were observed mainly in the rainy period, being associated to the diffuse charges and the contamination by sanitary sewers, contributing to alter the trophic degree, favoring the species in question. The physical characteristics of the region, agricultural activities and inadequate handling of the soil were relevant in great extension of the river Pará, where those effects were noticed with greater intensity. On the other hand, in the passage downstream of the reservoir located in the main course, there was an inversion of that situation as a consequence of the stabilization observed in dammed environments (IGAM, 2003).

The relation between the water quality and the agricultural use was already seen in other bodies of water in Brazil. Watanabe et al. (1994) showed an increase of nitrate contents in Açu River and in Gramame and Mamuaba Reservoirs (PB), indicating a contamination of these ecosystems due to the chemical fertilizers used in the sugarcane plantations. Ferreira et al. (1994) identified the intensive agriculture, the cultivated pastures and the urban effluents as the main factors of environmental alterations in Pantanal, Novo et al. (1995) for Barra Bonita Reservoir (SP), Ometo et al. (2000) for Piracicaba River basin (SP), and Rull Del Aguila (2001) for Furnas Reservoir (MG).

In the Paraopeba River sub-basin, the occurrence of $T$. decipiens was registered in the reservoirs of Várzea das Flores (Freire and Pinto-Coelho, 1986; COPASA, 1999), Serra Azul and Rio Manso (COPASA, 1999) and Ibirité (Pinto-Coelho et al., 1998). WQI along the river Paraopeba showed medium values. The counting of fecal coliform exceeded the legal patterns in most of the analyses carried out in the sub-basin, constituting a relevance indicator about the degradation of the waters of the region by effluents of sanitary sewers (IGAM, 2003).

The Betim River presented the worst conditions of Paraopeba River sub-basin, indicating pressures of sanitary sewers effluents and other organic spillages. WQI was bad in this river downstream Várzea das Flores Reservoir, close to its mouth in Paraopeba River, a more critical region regarding 
the values of phosphate. The most expressive values of increase of the concentrations of total phosphate were also registered in Betim River, with a maximum of $2.39 \mathrm{mg} . \mathrm{L}^{-1}$. Phosphate concentrations in the waters of this sub-basin were specially important, once they were drained to Três Marias Reservoir, where the occurrence of $T$. decipiens was also registered. The sub-basin of this tributary is a region of intense urban and industrial development.

Betim River is the main tributary of Varzea das Flores Reservoir, established in 1979. The largest densities of $T$. decipiens were registered close to the tributaries (Betim River and Água Suja stream), where the values of electric conductivity were high and the values of transparency of the water were lower. Together with $T$. decipiens, high densities of Ceriodaphnia spp. and Conochilus sp. were also registered, associated to eutrophic conditions (Freire and Pinto-Coelho, 1986).

The reservoir of Ibirite is also located in this subbasin at the, metropolitan area of Belo Horizonte. According to Pinto-Coelho et al. (1998), it is a small reservoir that is suffering an accelerated eutrophication process, mainly through the diffuse charges of organic matter carted by the streamlet Ibirite. The limnologic conditions of this reservoir are deteriorating sharply, during the dry season, when intense increases in ammonia contents and electric conductivity occur, and not very rare, blooms of cyanobacteria, mainly Microcystis spp. (Pinto-Coelho et al., 1998).

Although cyanobacteria are usually considered ineffective as food for zooplankton (Junk, 1984), a lot of evidences exist that $T$. decipiens and some congeneric species can explore them (Reid, 1989). This species is a representative of the zooplankton, dominant or quantitatively important in several lakes and eutrophic neotropical reservoirs, in which the phytoplankton tends to be dominated by one or several cyanobacteria species. In these systems, populations of $T$. decipiens tend to stay stable or at least abundant all year round (Reid, op. cit.).

In some eutrophic reservoirs, with cyanobacteria occurrence, as the lake Paranoá, in Brasília (DF) (Freitas, 1983; Giani, 1984; Pinto-Coelho, 1983; 1987) as well as the Complexo Billings, in the state of São Paulo (Sendacz et al., 1984), populations of $T$. decipiens tend to exibhit smaller variations than other crustaceans. According to Matsumura-Tundisi, et al. (1997) the great abundance of Cyclopoida in eutrophic systems is related to cyanobacteria blooms that form great colonies with mucilage, only Cyclopoida, with a raptorial feeding habit could use these cyanobacteria. According to Rietzler (1995), cyanobacteria represent an important complementary source of food for Cyclopoida. Also, Rietzler and Espíndola (1998) verified that Microcystis constituted a food source for copepods in an eutrophic reservoir (Barra Bonita). Sampaio et al. (2002) found positive correlation between the abundance of $T$. decipiens and cyanobacteria of a eutrophic reservoir (Barra Bonita).

Still in the basin of the river São Francisco, small number of individuals of the species $T$. decipiens was registered in Três Marias Reservoir, what allowed to infer that this reservoir was still in good conditions of water quality, although a medium WQI was obtained for great part of the basin of São Francisco River basin. This was associated with effluents of sanitary sewers and agrosilvopastoral activities developed in the area. In the sub-basin of the River das Velhas, the species was found in high densities in three water bodies in the metropolitan area of Belo Horizonte: Lagoa Santa, Pampulha Reservoir and the reservoir of the Pontifícia Universidade Católica de Minas Gerais (PUC-Minas reservoir). The WQI, of River das Velhas, in the metropolitan area presented medium to very bad rates.

In Lagoa Santa, the species was registered in 1985 , where trophic conditions were meso to eutrophic (Reid et al., 1988; Barbosa et al., 1984). This environment has been studied for several years and the results show an evolution of the trophic degree. In the collections carried out in the year 2002, in Lagoa Santa, for this study, the populations of $T$. decipiens were very abundant, confirming once again the adaptation of the species to eutrophic environments.

In the case of the Pampulha Reservoir, the situation has become more and more critical, because practically the sub-basins of all the eight tributaries are placed in urbanized areas whose domestic wastes are received directly by in the tributaries (Freitas et al., 1994; Barbosa et al., 1997), taking it to an increasing level of eutrophication of the reservoir.

The total phosphorus is a good indicator of cyanobacteria increase. The dominance of these organisms is known as a pollution symptom or ecological unbalance in planktonic communities (Giani, 1994). According to Pinto-Coelho et al. (1999), Cylindrospermopsis raciborskii was the 
taxon with greater number of individuals in the phytoplanktonic community Pampulha Reservoir in the period of 1984 - 1985, the same period, that Cyclopoida reached high densities. During the collections accomplished for the present study, in the period from 2000 to 2002, T. decipiens kept dominant. Also in the metropolitan area of Belo Horizonte, the reservoir of PUC-Minas, where $T$. decipiens was found in high densities, presented indicative characteristics of high trophic degree (Landa and Landa, 2001).

In the basin of Doce River, most of the main water bodies studied presented medium WQI, although in the proximities of the cities of Itabira and Nova Era, WQI was bad. One of the places of occurrence of $T$. decipiens was the Pontal reservoir, in the municipal district of Itabira. This reservoir, supplied by tributaries of Peixe River, according to IGAM (2003) presented bad WQI, was built to contain the reject of the "wash" of the iron ore and supply the industrial compound of the Companhia Vale do Rio Doce. According to Dabés et al. (1990), in 1987 this reservoir presented eutrophic characteristics, including high cyanobacteria densities. The other two places of occurrence of the species correspond to a medium WQI, considering the great contribution of diffuse pollution.

In the basin of Grande River, T. decipiens was registered at seven places. Of these, four were in the municipal district of Lavras, in the Campus of the Universidade Federal de Lavras (UFLA). It refered to three small reservoirs (Estação, Nova e Pomar) and a lotic passage of drainage of these reservoirs for the Station of Fish farming, having all four water bodies eutrophic characteristics. In the three reservoirs, the occurrence of $T$. decipiens and T. minutus was registered, the first one always more abundant (Landa and Mourgués-Schurter, 1999; 2000a).

According to Reid (1989), the co-occurrence of those two species indicated that the environmental conditions were not stable. A greater abundance of $T$. decipiens in three reservoirs reinforced the suggestion of the existence of a relation of those species with the physical and chemical conditions of the environment, therefore indicating the trophy degree. This relation was evident in the lotic passage that supplied the Station of Fish farming (Landa and Mourgués-Schurter, 2000b), and for the improved conditions after the junction of the effluents, where the species $T$. minutus was more frequent and abundant, what confirmed its preference for oligo-mesotrophic waters (Dabés, 1995).

Still in the Grande River basin, T. decipiens was also found in the reservoirs of Furnas, Igarapava and Volta Grande. In 2002, WQI of Grande River was good in the passages monitored downstream of the Furnas Reservoir and medium in most of the passages located upstream of the same reservoir. Although Furnas Reservoir presented low ionic concentrations and high values of transparency of the water column (Figueredo, 2000), the existence of non-treated sewer contribution in the reservoir, or in some of their tributaries, as well as the high time of residence of the water (160 days) and its dendritic morphology, made Furnas perform a distinguished influence in the water quality and in the trophic state (Sá Júnior, 1994). According to Rull Del Aguila (2001), the highest values of density of $T$. decipiens were registered in the more eutrophic areas of the reservoir.

Most of the places where $T$. decipiens was registered corresponded to passages of basins with high urban occupation. The existence of correlation between the ammonia and the urban population confirmed the existence of human occupation impact in the water quality through the effluents of non-treated sewers in the body of water. The main sources of ammonia are the animal excretion, the organic matter degradation by bacteria (McCarthy, 1980), the superficial drainage through the rivers and, indirectly from the fixation of $\mathrm{N}_{2}$ by bacteria in anaerobic conditions. The ammonia seemed to be a strong indicative of an environmental degradation process linked to urban occupations in several types of aquatic environments. In the southeast of Brazil, several studies have demonstrated this relation, such as Ometo et al. (2000) in the state of São Paulo, and Rull Del Aguila (2001) in Furnas (MG).

Downstream Furnas, also in the main course of Grande River, Igarapava Reservoir presented good WQI, in spite of the agriculture and stockbreeding activities developed in the region that affected in an indiscriminate way the micro basins, mainly increasing the levels of nitrate and phosphate. Although T. decipiens was found in this reservoir, this species was not registered in great densities, reflecting its incompatibility with environments with low trophic-levels.

The value of WQI registered in 2002 for the Volta Grande Reservoir, downstream of Igarapava, was considered good. According to Greco (2002), 
Volta Grande Reservoir presented oligomesotrophic conditions in its limnetic area. This was confirmed by the absence of oxygen deficit at the bottom, by the high water transparency values, low phosphorus and chlorophyll-a concentrations, and dominance of calanoid copepods in the zooplankton. In this environment, T. decipiens also occurred in low densities.

As a conclusion, a relation was observed between the occurrence and the density of $T$. decipiens and the trophic degree of collections of water in different watersheds of Minas Gerais, corroborating the use of this species as indicative of trophic degree and of water quality, and constituting, therefore, an important tool in the biomonitoring of aquatic ecosystems: In the Paranaíba River basin, the main problems of water quality registered in the period of 2002 and 2003 were associated to the effluents of gross sanitary sewers and the inadequate use and handling of the soil, which increased nitrogen and phosphorus concentrations, favoring the predominance of species such as $T$. decipiens. The higher densities of $T$. decipiens were in the reservoirs of Ibirité, Vargem das Flores and Pampulha, all three of them inserted in São Francisco River basin, in Paraopeba and Rio das Velhas sub-basins, which presented the highest percentage of occurrence of bad and very bad water quality. The presence of $T$. decipiens in small densities in Grande River basin reinforced even more the existence of a relation of this species with the trophic degree, because the reservoirs of Volta Grande, Igarapava and Furnas were not considered eutrophic.

\section{ACKNOWLEDGEMENTS}

We thank to CEMIG for the use of the database SISAGUA, to COPASA for the consultation in the internal reports, to IGAM for the supply of the documents of water quality of the State of Minas Gerais, to Professors Juan C. Paggi and Susana Jose de Paggi of the National Institute of Limnology (INALI - Argentina) for the suggestions, support, incentive and also for the confirmation of the species Thermocyclops decipiens.

\section{RESUMO}

Thermocyclops decipiens é uma espécie pioneira de grande dispersão e altamente adaptável a colonizar novos ambientes. É comumente encontrada no sudeste do Brasil, em ambientes com características meso e eutróficas. Considerando a dominância desta espécie no reservatório da Pampulha e a sua provável relação com o grau de trofia, este trabalho objetivou verificar a possibilidade de utilizar este organismo como indicador do grau de trofia e/ou qualidade de água de algumas bacias hidrográficas do Estado de Minas Gerais. Para isso, foi feita uma revisão sobre a ocorrência da espécie no Estado. A partir dos anos 90, T. decipiens foi registrada em várias coleções de água do Estado, abrangendo as bacias dos rios Paranaíba, São Francisco, Doce e Grande, na sua grande maioria, com características meso e eutróficas. Dos 28 locais de ocorrência da espécie, e conforme o índice de qualidade de água (IQA) utilizado pela FEAM, 7 destes ambientes apresentam IQA bom, 16 um IQA médio, 4 um IQA ruim e um IQA muito ruim. Esta classificação reforça a hipótese de que $T$. decipiens pode ser utilizada como espécie indicadora de ambientes eutróficos e de baixa qualidade de água, e como tal, constitui ferramenta importante no biomonitoramento de ecossistemas aquáticos.

\section{REFERENCES}

Barbosa, F.A.R.; Coutinho, M.E.; Araújo, L.M.; Menendez, R.M.; Barbosa, P.M.; Figueira, J.E.C. and Esteves, F.A. (1984), Estudos limnológicos na região cárstica central de Minas Gerais. I. Caracterização preliminar da Lagoa Santa. In: Anais do IV Seminário Regional de Ecologia. pp. 399-437.

Barbosa, F.A.R.; Souza, E.M.M.; Vieira, F.; Renault, G.P.C.P.; Rocha, L.A.; Barbosa, P.M.; Oberdá, S.M. and Mingoti, S.A. (1997), Impactos antrópicos e biodiversidade aquática. In: Biodiversidade, População e Economia: uma região de Mata Atlântica. Rona Editora/UFMG/CEDEPLARECMVS/PADCT-CIAMB, Belo Horizonte, pp.345454.

Bonetto, A .A. and Martínez de Ferrato, A. (1966), Introducción al estudio del zooplancton de las cuencas isleñas del Paraná Medio. Physis, 26, 385396. 
Carvalho, M.A.J. (1975), A Represa de Americana: aspectos físico-químicos e variação das populações de Copepoda Cyclopoida de vida livre. 80p. Tese (Doutorado) - Instituto de Biociências, Universidade de São Paulo, São Paulo.

CEMIG - Companhia Energética de Minas Gerais (1994), Banco de dados SISAGUA. Belo Horizonte. CD.

CETESB - Companhia de Tecnologia de Saneamento Ambiental (1989), Relatório de Qualidade de Águas Interiores do estado de São Paulo. Secretaria do Meio Ambiente/Governo do estado de São Paulo. $166 \mathrm{p}$.

CONAMA. Resolução $\mathrm{n}^{\mathrm{o}}$ 20, de 18/06/86 Diário Oficial, Brasília, pp. 72-89.

COPASA - Companhia de Saneamento de Minas Gerais (1999), Belo Horizonte, Relatórios Internos.

Dabés, M.B.G.S.; França, R.C.; Gomes, M.C.S.; Junqueira, M.V.; Rolla, M.E. and Rosa, S.G. (1990), Caracterização limnológica da represa de Pontal, Itabira (MG). Acta Limnol. Brasil, 3, 173-199.

Dabés, M.B.G.S. (1995), Composição e descrição do zooplâncton de cinco lagoas marginais do Rio São Francisco, Pirapora, Três Marias, Minas Gerais Brasil. Rev. Brasil. Biol., 55: (4 ), 831-845.

Ferreira, C.J.A.; Soriano, B.M.A.; Galdino, S. and Hamilton, S.K. (1994), Antropogenic factors affecting waters of the Pantanal wetland and associated rivers in the upper Paraguay River basin of Brazil. Acta Limnol. Brasil., 5, 135-148.

Freire, B.M. and Pinto-Coelho, R.M. (1986), Composição e distribuição horizontal do zooplâncton no Reservatório de Vargem das Flores, Betim/Contagem, Minas Gerais. Ciência e Cultura, 35: (5), 919-927.

Freitas, J.S. (1983), Variação sazonal e distribuição vertical de microcrustáceos planctônicos no Lago Paranoá, DF. Dissertação (Mestrado em Ecologia) Universidade de Brasília, Brasília.

Freitas, J.R.; Santos, M.B.L.; Rocha, L.A. and Bedê, L.C. (1994), Competitive interactions among mollusks in urban reservoirs, ponds and lakes. In: Ecology and human impact on lakes and reservoirs in Minas Gerais with special reference to future development and management strategies, R.M.PintoCoelho et al. SEGRAC, Belo Horizonte, pp. 165-188.

Giani, A. (1984), Distribuição horizontal do fitoplâncton e zooplâncton no Lago Paranoá, Brasília, DF, Brasil. Dissertação (Mestrado em Ecologia) - Universidade de Brasília, Brasília.

Giani, A. (1994), Limnology in Pampulha Reservoir: some general observations with emphasis on the phytoplankton community. In: Ecology and human impact on lakes and reservoirs in Minas Gerais with special reference to future development and management strategies, ed. R.M. Pinto-Coelho, A. Giani and E. von Sperling. SEGRAG, Belo Horizonte, pp. 151-163.
Greco, M.K.B. (2002), Balanço de massa de fósforo, evolução da eutrofização e o crescimento de macrófitas flutuantes no reservatório de Volta Grande (MG/SP). Tese (Doutorado em Ecologia, Conservação e Manejo de Vida Silvestre) - Instituto de Ciências Biológicas, Universidade Federal de Minas Gerais, Belo Horizonte.

Hutchinson, G.E. (1951), Copepodology for the Ornithologist. Ecology, 32, 571-577.

IGAM - Instituto Mineiro De Gestão Das Águas (2003), Qualidade das Águas Superficiais do Estado de Minas Gerais em 2002. Belo Horizonte.

Junk, W.J. (1984), Ecology of the varzea, floodplain of Amazonian white-water rivers. In: The Amazon: Limnology and Landscape Ecology of a Mighty Tropical River and its Basin, ed. W.J.Junk, The Hague, pp. 215-243.

Kiefer, F. (1938), Die von der Wallacea-Expedition gesammelten Arten der Gattung Thermocyclops Kiefer. Int. Rev. Gesamten Hydrobiol., 38, 54-74.

Landa, G.G. and Landa, F. de S.L. (2001), Limnologia de um Sistema Lêntico Raso (Represa do Campus da Pontifícia Universidade Católica de Minas Gerais, Belo Horizonte, MG - PUC-Minas/BH) I Características morfométricas e físico-químicas. Bios, 9: (9), 63-71.

Landa, G.G. and Mourgues-Schurter, L.R. (2000a), Composição e abundância do zooplâncton de duas represas do Campus da Universidade Federal de Lavras, Minas Gerais, Brasil. Acta Limnol. Brasil., 12: (2), 29-43.

Landa, G.G. and Mourgues-Schurter, L.R. (2000b), Características físico-químicas e biológicas (zooplâncton) da água que abastece a Estação de Piscicultura da Universidade Federal de Lavras MG. B. Inst. Pesca, 26 : (2), 223-232.

Lansac-Tôha, F.A.; Lima, A.F.; Thomaz, S.M. and Roberto, M.C. (1992), Zooplâncton de uma planície de inundação do rio Paraná. I. Análise qualitativa e estrutura da comunidade. Revista Unimar, 14 (Supl.), 35-55.

Lansac-Tôha, F.A.; Velho, L.F.M.; Higuti, J. and Takahashi, E.M. (2002), Cyclopidae (Crustacea, Copepoda) from the upper Paraná river floodplain, Brazil. Braz. J. Biol., 62: (1), 125 - 133.

Martínez de Ferrato, A. (1967), Notas preliminares sobre migraciones del zooplancton en cuencas isleñas del Paraná Medio. Acta zool. Lilloana, 23, 173-188.

Matsumura-Tundisi, T.; Rocha, O. and Tundisi, J.G. (1997), Carbon uptake by Scolodiaptomus corderoi and Thermocyclops minutus on different size fractions of phytoplankton from Lake Dom Helvécio. In: TUNDISI, J.G.; SAIJO, Y. (Eds.). Limnological Studies onthe Rio Doce Valley Lakes. TundisiI, J.G. and Saijo, Y. (Eds.). Acad. Bras. Cie. Publ., Rio de Janeiro, pp. 275-284. 
McCarthy, J.J. (1980), Nitrogen. In: The physiological ecology of phytoplankton. Morris, I. (Ed.) Blackwell Biological Scientific Publications, Oxford, 625pp. (Studies in Ecology 7).

Menu-Marque, S.A. (1982), Thermocyclops decipiens (Kiefer, 1929) una nueva especie para la fauna argentina (Copepoda, Cyclopoida). Physis, 41, 41-46.

Novo, E.M.L.M.; Lobo, F. and Calijuri, M.C. (1995), Remote sensing and geographical information system application to inland water studies. In: Limnology in Brazil. Tundisi, J.G.; Bicudo, C.E.M.; MatsumuraTundisi, T. (Eds.) Brazilian Academy of Sciences and Brazilian Limnological Society, Rio de Janeiro, pp. 283-303.

Ometo, J.P.H.B.; Martinelli, L.A.; Ballester, M.V.; Gessner, A.; Krusche, A.V. Victoria, R.L. and Williams, M. (2000), Effects of land use on water chemistry and macroinvertebrates in two streams of the Piracicaba river basin, southeast Brazil. Fresh. Biol., 44, 327-337.

Paggi, J.C. and Jose de Paggi, S. (1990), Z Zooplâncton de ambientes lóticos e lênticos do rio Paraná Medio. Acta Limnol. Brasil., 3, 685-719.

Pinto-Coelho, R.M. (1983), Flutuações sazonais e de curta duração na comunidade zooplanctônica do Lago Paranoá, Brasília - DF, Brasil. Dissertação (Mestrado em Ecologia) - Universidade de Brasília, Brasília.

Pinto-Coelho, R.M. (1987), Flutuações sazonais e de curta duração na comunidade zooplanctônica do Lago Paranoá, Brasília-DF, Brasil. Revta. Bras. Biol., 47, 17-29.

Pinto-Coelho, R.M.; Nunes, C.M.S.; Barbeitos, M.; Morais, C.A. and Guerra, S.T. (1998), O impacto da Refinaria Gabriel passos na estruturação da comunidade zooplanctônica no reservatório de Ibirité, Betim, Minas Gerais. Bios, 6 : (6), 11-19.

Pinto-Coelho, R.M.; Coelho, M.M.; Espírito Santo, M.M. and Cornelissen, T.G. (1999), Efeitos da Eutrofização na Estrutura da Comunidade Planctônica na Lagoa da Pampulha, Belo Horizonte, MG. In: Ecologia de Reservatórios: Estrutura, Função e Aspectos Sociais. HENRY, R. (Ed.). FUNDIBIO/FAPESP, Botucatu, pp. 551-572.

Reid, J.W. (1985), Chave de identificação e lista de referências bibliográficas para as espécies continentais sulamericanas de vida livre da ordem Cyclopoida (Crustacea, Copepoda). Bol. Zool., 9, 17143.

Reid, J.W. (1989), The distribution of species of the genus Thermocyclops (Copepoda, Cyclopoida) in the western hemisphere, with desciption of $T$. parvus, new species. Hydrobiologia, 175, 149-174.

Reid, J.W.; Pinto-Coelho, R.M. and Giani, A . (1988), Uma apreciação da fauna de copépodos (Crustacea) da região de Belo Horizonte, com comentários sobre espécies de Minas Gerais. Acta Limnol. Brasil., 2, 527-547.
Rietzler, A .C. (1995), Alimentação, ciclo de vida e análise da coexistência de espécies de Cyclopoida na Represa de Barra Bonita, São Carlos - São Paulo. Tese de Doutorado. Escola de Engenharia de São Carlos, Universidade de São Paulo, São Carlos.

Rietzler, A .C. and Espíndola, E.L.G. (1998), Microcystis as a food source for copepods in a subtropical eutrophic reservoir. Verh. Internat. Verein. Limnol., 26, 2001-2005.

Rocha, O ; Sendacz, S. and Matsumura-Tundisi,T. (1995), Composition, biomass and productivity of zooplankton in natural lakes and reservoirs of Brazil. In: Limnology in Brazil. Tundisi, J.G.; Bicudo, C.E.M.; Matsumura-Tundisi, T. (Eds.). Academia Brasileira de Ciências/ Sociedade Brasileira de Limnologia, Rio de Janeiro, pp. 151-165.

Rull Del Aguilla, L.M. (2001), Gradiente trófico no rio Sapucaí (Reservatório de Furnas - MG): relação com a distribuição do zooplâncton e os usos do solo. Dissertação (Mestrado em Ecologia, Conservação e Manejo da Vida Silvestre) - Instituto de Ciências Biológicas, Universidade Federal de Minas Gerais, Belo Horizonte.

Ryding S. and Rast W. (1989), El control de la eutrofización en lagos y pantanos. 1. ed. Madrid: Ediciones Pirámide.

Sá Jr., W. P. (1994), Production of planktonic biomass for feed of alevins at the Furnas hydrobiology and hatchery station. In: Ecology and human impact on lakes and reservoirs in Minas Gerais with special reference to future development and management strategies. R.M. Pinto-Coelho, A. Giani and E. von Sperling. SEGRAG, Belo Horizonte, pp. 133-139.

Sampaio, E.V. ; Rocha, O.; Matsumura-Tundisi, T. and Tundisi, J.G. (2002), Composition and abundance of zooplankton in the limnetic zone of seven reservoirs of the Paranapanema river, Brazil. Braz. J. Biol., 62: (3), 525-545.

Sampaio, E.V. and López, C.M. (2000), Zooplankton community composition and some limnological aspects of na oxbow lake of the Paraopeba River, São Francisco River basin, Minas Gerais, Brazil. Brazilian Archives of Biology and Technology, 43: (3), 285-293.

Sendacz, S. and Kubo, E. (1982), Copepoda (Calanoida e Cyclopoida) de reservatórios do Estado de São Paulo. B. Inst. Pesca, 9, 51-89.

Sendacz, S.; Kubo, E. and Fujiara, L.P. (1984), Further studies on the zooplankton community of an eutrophic reservoir in southern Brazil. Verh. Int. Ver. Limnol., 22, 1625-1630.

Silva, M.W. (1998), Caracterização do reservatório de Nova Ponte (MG) nos meses de julho (seca) e fevereiro (chuvoso) com ênfase na composição $e$ distribuição do zooplâncton. Dissertação (Mestrado) - Escola de Engenharia de São Carlos, Universidade de São Paulo, São Carlos. 
Watanabe, T.; De Oliveira, R.B.; Sassi, R.; Melo, G.N.; Moura, G.F.; Gadelha, C.L. and Machado, V.M.N. (1994), Evidences of contamination caused by sugarcane monocultures and associated industrial activities in water bodies of the state of Paraíba, Northeast Brazil. Acta Limnol. Brasil., 5, 85-101.

Received: June 27, 2005;

Revised: May 31, 2006; Accepted: March 12, 2007. 
PÁGINA

EM

BRANCO 